\title{
BMJ Global Health Revolving doors and conflicts of interest in health regulatory agencies in Brazil
}

\author{
Mário C Scheffer (D) ,' Maria Pastor-Valero \\ Ildefonso Hernández-Aguado (D) 2,3
}

To cite: Scheffer MC, Pastor-Valero M, Russo G, et al. Revolving doors and conflicts of interest in health regulatory agencies in Brazil. BMJ Global Health 2020;5:e002325. doi:10.1136/ bmjgh-2020-002325

Handling editor Eduardo Gómez

- Additional material is published online only. To view please visit the journal online (http://dx.doi.org/10.1136/ bmjgh-2020-002325).

Received 19 January 2020 Revised 1 March 2020 Accepted 21 March 2020

Check for updates

C Author(s) (or their employer(s)) 2020. Re-use permitted under CC BY-NC. No commercial re-use. See rights and permissions. Published by BMJ.

'Preventative Medicine, Universidade de São Paulo Faculdade de Medicina, São Paulo, Brazil

${ }^{2}$ Departamento de Salud Pública, Historia de la Ciencia y Ginecología, Universidad Miguel Hernández, Elche, Spain ${ }^{3}$ Centro de Investigación Biomédica de Epidemiología y Salud Publica (Ciberasp), Madrid, Spain

${ }^{4}$ Institute for Population Health Sciences, Queen Mary University of London, London, UK

Correspondence to Dr Mário C Scheffer; mscheffer@usp.br

\section{INTRODUCTION}

Regulatory health agencies exist in most public health systems (PHS) and play a crucial role in enacting regulation and overseeing economic activities in order to ensure the quality of health systems, goods and services. ${ }^{1}$ Multiple practices of corruption such as bribery or fraud have been reported in health policy and systems. ${ }^{2}$ Public health agencies are particularly susceptible to 'regulatory capture, ${ }^{34}$ a process by which an agency advances the special interests of the industries and of other actors it is entrusted with regulating. One of the mechanisms that can potentially lead to an agency capture is the so-called 'revolving door' ${ }^{5}$ the situation where an exchange of roles between public regulators and regulated institutions may result in health policy decisions which are biased in favour of industry interests.

Revolving doors have previously been described in the USA and Europe, with an emphasis on legislative, energy, financial and patent agencies. However, there is little empirical evidence on the scale and scope of this problem in PHS. In this commentary, we explore the extent of the revolving doors phenomenon in Brazil by analysing the professional trajectories of public agents who held high positions at the two key health regulatory agencies in the country between 1999 and 2018.

\section{EXPLORING REVOLVING DOORS IN HEALTH REGULATORY AGENCIES IN BRAZIL}

We select the two federal health regulatory agencies linked to the Ministry of Health in Brazil: the National Health Surveillance Agency (ANVISA), which regulates drugs, food, cosmetics, tobacco, medical products and equipment, blood and blood products, hospitals and health services (box 1); and the National Agency of Supplementary Health (ANS), which regulates private health plans
Summary box

The 'Revolving Doors' phenomenon is both controversial and common worldwide, but little evidence exists from health sectors in low and middle-income countries (LMIC).

- We analyse the circulation of agents from regulatory to regulated entities in Brazil's two main health regulatory agencies.

- Almost half of the executives from such agencies in the last 20 years either started in or ended up working for the private health sector.

- We discuss paths and potential implications of such phenomenon for the quality of regulation of health markets in LMIC settings.

and insurance, including the relationship between these companies and suppliers, hospitals, diagnostic laboratories, physicians and private care users (box 2).

Despite Brazil's vast public and universal health system, there is a widespread presence of the private sector in the production, financing and delivery of health services. ${ }^{6}$ The private health insurance market in Brazil (the second largest in the world, after the USA) was estimated to be worth US $\$ 50.2$ billion in 2018 , and the Brazilian pharmaceutical market (the world's sixth largest) recorded a turnover of US $\$ 21.1$ billion in 2017. Therefore, there are major economic interests involved in the sectors regulated by both agencies.

By law, both agencies have collegiate boards consisting of five directors with 3-year terms, which can be renewed. After obtaining ethical approval, we appraised the professional trajectory of the 36 directors who held the highest positions (chief executive officer or similar functions) since the launch of the agencies in 1999 until 2018. We analysed the candidates' curricula vitae published by the Federal Senate, including information on previous job affiliation and timing of their appointment for a position as director at any of the two agencies under evaluation. As a way 
Box 1 Brazil's National Agency of Supplementary Health (ANS) in 2018

Its structure: five directors and 1225 staff. Budget of $\mathrm{R} \$ 347.2$ million (US\$88 million). Its mission and area of practice: economic and financial regulation, healthcare regulation, oversight and inspection of private health insurance market.

Characteristics of the sector regulated by ANS: population with a private health insurance in Brazil 47.4 million. One thousand two hundred and twenty-six health insurance and plans companies; 140120 health service providers funded through health plans in Brazil; overall turnover for the private health insurance sector $\mathrm{R} \$ 145$ billion.

Source: ANS Annual Report (2018).

to complement the missing information, we searched the public professional data available online by the ANS and ANVISA websites about the directors' professional activities during their tenure. We consulted self-reported information on public curriculum platforms and professional online networks in order to examine their professional activities after leaving the agencies. This information was then double checked with the public records from employers.

\section{EXECUTIVES SERVING IN HEALTH REGULATORY AGENCIES AND PRIVATE COMPANIES}

From 1999 to 2018, 36 professionals held executive positions at the two health regulatory agencies in Brazil: 17 were directors of ANVISA and 18 were directors of ANS. One professional was a director of both agencies in consecutive periods.

We identified three professional trajectories of the former directors in and out the regulatory agency (figure 1): (A) professionals employed in public administration before and after serving as agency directors were categorised into the 'Public-Public' group $(n=20 ; 55.5 \%)$; (B) 'Public-Private' modality $(\mathrm{n}=11 ; 30.5 \%)$, referring to those who worked in the public sector before becoming agency directors and migrated to the private sector after leaving the public agency; and (C) professionals who held job positions in the private sector before and after

\section{Box 2 The National Health Surveillance Agency (ANVISA)}

Its structure: five directors and 2156 staff. Budget of $\mathrm{R} \$ 861.15$ million (US\$218 million). Its mission and area of practice: economic and financial regulation, healthcare regulation, oversight and inspection pharmaceuticals, food, health technology, tobacco control and other potentially health hazardous products, immunobiological products, blood, organs and products of human origins, agricultural products, cosmetics, perfumes and hygiene products.

Examples of ANVISA's 2018 activities in 2018: 827 new pharmaceutical compounds approved for the Brazilian market; 1356 new cosmetics approved; 106 approvals/alterations for agricultural products; 9135 inspections carried out to health service providers.

Source: ANVISA Annual Report (2018).
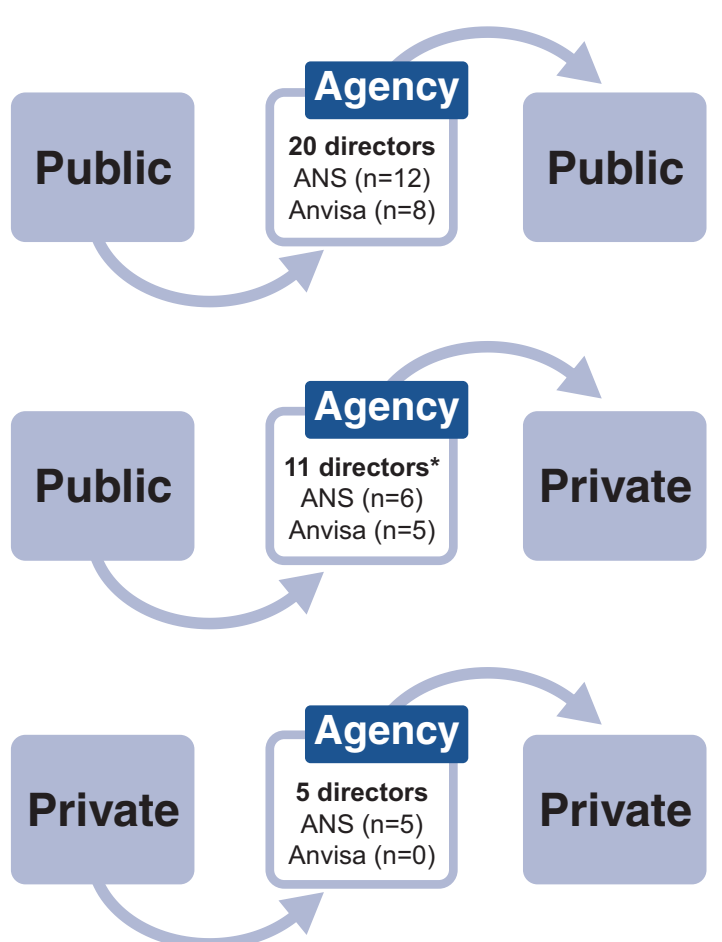

* In the 'Public-Private' group, one professional was director of National
Health Surveillance Agency (Anvisa) for 1 year and consecutively
director of National Agency of Supplementary Health (ANS) for 3 years.

Figure 1 Public and private job positions of ANVISA and ANS former directors (1999-2018).

being directors of the public agency were categorised in the 'Private-Private' group $(\mathrm{n}=5 ; 14.0 \%)$. Almost half of the former directors $(n=16 ; 44.5 \%)$ were involved in revolving doors (see anonymised list in online supplementary file).

The most common management positions in the private sector were in health plans and insurance companies $(n=4)$, private hospitals $(n=4)$ and the pharmaceutical industry $(n=3)$. Another five ex-directors provided consulting services to more than one sector, such as drug companies, hospitals and health plan providers, or medical equipment, biotechnology, cosmetics, pesticides, food, beverages and tobacco industries.

According to the characteristics of the trajectory prior to working in the agencies (table 1), there were more professionals with health science education and who had previously worked within the Brazilian Unified Health System in the 'public-public' group than in the other two groups. Yet, there were some cases of public career officers who migrated to the private sector after working in public agencies.

Our results show that former directors who participated in drug approval decisions at the agency later began work for the pharmaceutical industry. For example, records of meeting minutes and public documents available from government websites revealed that 
Table 1 Higher education curriculum and professional trajectory of former directors of the National Health Surveillance Agency (ANVISA) and National Agency of Supplementary Health (ANS), from 1999 to 2018. Brazil, 2019

\begin{tabular}{|c|c|c|c|c|c|c|}
\hline \multirow[b]{2}{*}{ Characteristics } & \multicolumn{2}{|c|}{$\begin{array}{l}\text { Public-public } \\
(n=20)\end{array}$} & \multicolumn{2}{|c|}{$\begin{array}{l}\text { Public-private } \\
(n=11)\end{array}$} & \multicolumn{2}{|c|}{$\begin{array}{l}\text { Private-private } \\
(\mathrm{n}=5)\end{array}$} \\
\hline & $\mathbf{n}$ & $\%$ & $\mathbf{n}$ & $\%$ & $\mathbf{n}$ & $\%$ \\
\hline Graduated in health sciences & 17 & 85 & 4 & 36 & 4 & 80 \\
\hline Degree in public health & 7 & 35 & 2 & 18 & - & - \\
\hline Public career officer & 15 & 75 & 3 & 27 & - & - \\
\hline Hold position based on trust, but not a public career officer & 4 & 20 & 9 & 82 & - & - \\
\hline Previously worked for the public health system (SUS) & 16 & 80 & $5 a$ & 45 & & \\
\hline Previously worked at public government agency outside health system & 2 & 10 & 8 & 73 & & \\
\hline Previously worked in the private health sector & - & & $1 b$ & 8 & 5 & 100 \\
\hline Nominated by right-wing (PSDB) party & 5 & 25 & 3 & 27 & - & - \\
\hline Nominated by left-wing (PT) party & 15 & 75 & 8 & 73 & 5 & 100 \\
\hline
\end{tabular}

(A) One former director has worked in a public health agency and another non-health public agency; (B) one former director has worked in the private sector and in a trusted public position outside of health system; (C) Brazilian Social Democracy Party (PSDB) and (D) Workers Party (PT) are antagonistic political parties from the elected presidents during the study period.

ANS, National Agency of Supplementary Health; ANVISA, National Health Surveillance Agency; SUS, Unified Health System.

one of ANVISA's former directors granted a Certificate of Good Practice and authorised registries of medicines and pesticides marketed by a specific multinational pharmaceutical laboratory while working at the agency. Nearly 1 year after this director left the agency, s/he took over as director of regulatory policy and public affairs at the same laboratory, according to information from her/his LinkedIn profile, newsletters and public events.

This evidence corroborates other revolving door studies considering the postgovernment careers of state former employees and their previous professional jobs. For example, 11 out of 16 Food and Drug Administration (FDA) evaluators took on jobs or consultancy work for drug companies previously regulated and approved by themselves. ${ }^{7}$ Another study that examined the careers of former US Congress officials found that several officials became lobbyists after performing their duties as civil servants. In this study, even before being hired by the private sector, these employees strengthened their legislative portfolios and credentials in health, environment and commerce, which are themes valued by the lobby market. $^{8}$

All the directors we studied were found to receive support from politicians from opposing parties, on the occasion both of their designation by the Federal Government and their approval by the Federal Senate.

\section{THE IMPLICATIONS OF REVOLVING DOORS FOR HEALTH SYSTEMS WORLDWIDE}

Almost half of the ex-directors of ANVISA and ANS went to companies and sectors previously regulated and supervised by them, which indicates a high potential for regulatory capture. In other areas, such as the financial market, ${ }^{9}$ findings similar to those observed in this study have already been described. There are revolving doors from market to government offices that result in the designation of corporate executives at key agency positions, generating potential probusiness bias in regulatory activities.

Previous findings bring evidence for the potential damage-to the Brazilian health system and other systems-of the revolving door phenomenon in regulatory agencies. The robust analysis performed by Hong and $\operatorname{Lim}^{10}$ showed how the move from the post of deputy minister of education to the management of a private university in South Korea ensured financial benefits to the university that were not related to his competence but to its previous activity in the government. Similarly, an Australian study pointed to the potential risks of revolving doors for public health policies by showing that countless former government officials have started working for the alcohol, food and gambling industries, performing activities directly related to their previous government employment. ${ }^{11}$ Patent examiners employed by the US Patent and Trademark Office in the USA granted considerably more patents to companies that later hired them. ${ }^{12}$ Moreover, the revolving door has prompted US state insurance commissioners to be less strict in regulating the sector, with $38 \%$ of them leaving their public positions and to start working for insurance companies between 2000 and $2018 .^{13}$

There are also government revolving doors towards the market, whereby public officers take up positions at private companies, consulting firms, 'think tanks' or representative business associations-positions in which they can theoretically use their experience and connection networks within the administration to benefit their new employer.

Revolving door may lead to regulatory capture, ${ }^{14} 15$ presumed as when a public institution adopts policies proposed by regulated entities. Moreover, the transition between public and private job positions can result from 
the process of socialisation in the workplace, the interaction of social and professional networks, the attraction for professional status and the higher remuneration offered by the private sector.

However, the revolving door does not always imply, a priori, regulatory capture, as agencies can incorporate personnel and information from external interested parties that increase their intellectual and technical capacity. For example, a recent study showed that public purchases performed by employees who previously worked for private sector companies were financially more advantageous for public spending than purchases made by public employees with no previous experience in the private sector. ${ }^{16}$ This example also indicates that revolving door should also be studied with a focus on specific work processes and in lower hierarchical positions, when unexpected positive results may arise.

There are also records of conflicts of interest caused by revolving doors involving the FDA, ${ }^{17}$ the European Medicines Agency ${ }^{18}$ and agencies from the National Health Service $^{19}$ of the UK. Conflicts may range from drug companies funding clinical trials, ${ }^{20}$ to food and beverage manufacturers' strategies to avoid stricter regulation, ${ }^{21}$ or industry lobbying limiting nutritional labelling on packaging. ${ }^{22}$

Although some health agencies such as the UK National Institute for Health and Care Excellence ${ }^{23}$ and others have established transparent conflict of interest policies, the management of potential risks tends to be inadequate, and evidence of effective measures to overcome these ethical issues is at worst insufficient if not entirely non-existent. ${ }^{3}$

Despite the laws ${ }^{24}$ that have been established to avoid ethical misconduct in public services, the effectiveness of such regulations is questionable in Brazil. For example, the latency period that prevents former public employees from working for companies with a potential conflict of interest is only 6 months.

Our findings need to be weighed against some limitations. It deals with an exploratory national case limited to a defined period of time and the nature of public or self-reported data. The cross-sectional design does not show an association and evidence for direct causality, which would require further qualitative studies on professional trajectories that need to include measures of the positions taken by agency directors during and after their public careers. Our work does not aim at assessing the harmful or beneficial effects of the revolving door phenomenon in Brazil. Although the risks of such practice are more frequently reported in the literature, we acknowledge it could also be possible that experience and individual training in previous jobs can contribute to appropriate decisions and efficient measures, regardless of whether the professional transition is public-private or private-public.

The fact that the agency directors had received nonpartisan support, although none of them were rejected by the Federal Senate, suggests that future studies should consider possible political motivations behind these nominations. Furthermore, conflicts of interest in sectors regulated by agencies which previously funded political campaigns should be investigated. The senior executives and the hierarchically lower positions (chiefs, coordinators and advisers) should be included in future studies, which can also be expanded to other health agencies and legislative power.

\section{CONCLUSION}

Almost half of the executives who worked at Brazil's two main federal health regulatory agencies either started or ended up working for private companies regulated by these agencies. Such 'Revolving doors' in the health sector is a little-known phenomenon that has the potential to reduce the quality of government's regulation and public health policymaking.

Our commentary contributes to the literature and health policies in four ways. First, it provides evidence of existence of the wide extent of the revolving doors in the two health regulatory agencies in Brazil. Second, it reinforces the importance of including the health sector in revolving doors research and the need to adopt legislation to mitigate its effects. Third, it encourages researchers to focus on the revolving doors phenomenon in broader studies to highlight the potential of policymaking to confront corruption and conflicts of interest in health. It suggests, therefore, that the revolving doors in health regulatory agencies should be a specific object of study and regulation, considering its high frequency and its influence on both public health and the economics of health systems.

Our commentary may contribute to highlighting the extent of revolving doors and their effects, especially in light of the current financial and political crises that have driven many countries to a 'deregulatory' approach; weakening the control of public agencies and promoting more flexible regulation and legislation over market stakeholders. Healthcare trends on promoting publicprivate partnerships, privatisation and outsourcing have created grey areas of interaction between the private sector and public government institutions. These characteristics reinforce the relevance of studies on legal regulation of revolving doors. The legitimacy and effectiveness of health agency actions within health systems depend on their expertise and administrative and financial autonomy and independence, and on their ability to set limits to ensure that revolving doors do not benefit private interests over the quality, efficiency and economic soundness of PHS.

Contributors All authors were involved in drafting the article and revising it critically for important intellectual content, and approved the final version to be submitted for publication. MCS was responsible for the research and for analysing the data. MCS, IHA and MPV have contributed to the conception and design of the study. IHA coordinated the study. GR has contributed to the critical review of the study and the final version of the manuscript.

Funding This study received support from the Confap-MRC call for Health Systems Research Networks, comprising the following institutions: Newton Fund/ 
Medical Research Council (UK, grant reference MR/R022747/1-C0OPI-00709/18) and FAPESP (Brazil, 2017/50356-7). MCS was given a postdoctoral fellowship from the Fundación Carolina and Tordesillas Group 'Convocatória: C.2018. Estancia Corta Postdoctoral'

Competing interests None declared.

Patient consent for publication Not required.

Ethics approval 'Rio de Janeiro Federal University Ethics Committee (the research was approved by the Research Ethics Committee-CEP (IESC/UFRJ/ CAAE:55181216.6.0000.5286)).

Provenance and peer review Not commissioned; externally peer reviewed.

Data availability statement Data are available upon request.

Open access This is an open access article distributed in accordance with the Creative Commons Attribution Non Commercial (CC BY-NC 4.0) license, which permits others to distribute, remix, adapt, build upon this work non-commercially, and license their derivative works on different terms, provided the original work is properly cited, appropriate credit is given, any changes made indicated, and the use is non-commercial. See: http://creativecommons.org/licenses/by-nc/4.0/.

\section{ORCID iDs}

Mário C Scheffer http://orcid.org/0000-0001-8931-6471

Maria Pastor-Valero http://orcid.org/0000-0001-9282-5787

Giuliano Russo http://orcid.org/0000-0002-2716-369X

Ildefonso Hernández-Aguado http://orcid.org/0000-0003-1911-5759

\section{REFERENCES}

1 Field RI. Health care regulation in America: complexity, confrontation and compromise. New York: Oxford University Press, 2007.

2 Hutchinson E, Balabanova D, McKee M. We need to talk about corruption in health systems. Int $\mathrm{J}$ Health Policy Manag 2019;8:191-4.

3 Mindell JS, Reynolds L, Cohen DL, et al. All in this together: the corporate capture of public health. BMJ 2012;345:e8082.

4 Hernández-Aguado I, Chilet-Rosell E. Pathways of undue influence in health policy-making: a main actor's perspective. J Epidemiol Community Health 2018;72:154-9.

5 Thiel M, Bauer E, Runcan PI. Revolving doors in the EU and US. EPRS European parliamentary research service; 2018.

6 Paim J, Travassos C, Almeida C, et al. The Brazilian health system: history, advances, and challenges. Lancet 2011;377:1778-97.

7 Piller C. Is FDA's revolving door open too wide? Science 2018;361:21
8 Shepherd ME, You HYEY. Exit strategy: career concerns and revolving doors in Congress. Am Polit Sci Rev 2020;114:270-84.

9 Dinan W, Miller D. Revolving door, accountability and transparencyemerging regulatory concerns and policy solutions in the financial crisis. Paris: OCDE, 2009.

10 Hong S, Lim J. Capture and the bureaucratic mafia: does the revolving door erode bureaucratic integrity? Public Choice 2016;166:69-86.

11 Robertson NM, Sacks G, Miller PG. The revolving door between government and the alcohol, food and gambling industries in Australia. Public Health Res Pract 2019;29:e2931921.

12 Tabakovic H, Wollmann T. From revolving doors to regulatory capture? Evidence from patent examiners. NBER Working Paper 2018:w24638.

13 Tenekedjieva AM. The revolving door and insurance Solvency regulation Chicago. Dissertation [Booth School of Business]. University of Chicago, 2020.

14 Shapiro SA. The complexity of regulatory capture: diagnosis, causality, and remediation. Roger Williams UL Rev 2012;17:221-9.

15 Cuéllar MF. Coalitions, autonomy, and regulatory Bargains in public health law, in preventing regulatory capture: special interest influence in regulation and how to limit it. Cambridge University Press (Cambridge):Daniel Carpenter and David Moss, 2013.

16 Barbosa K, Straub S. The value of revolving doors in public Procuremente Tolouse. Monograph - Université Toulouse 1 Capitole, 2017.

17 Pham-Kanter G. Revisiting financial conflicts of interest in FDA Advisory committees. Milbank Q 2014;92:446-70.

18 Hawkes N. Lobby groups call for closure of "revolving door" between drug regulators and industry. BMJ 2011;343:d8335.

19 Oliver D. The revolving door to the NHS Lobby. BMJ 2019;365:i1297.

20 Sismondo S. Pharmaceutical company funding and its consequences: a qualitative systematic review. Contemp Clin Trials 2008;29:109-13.

21 Miller D, Harkins C, strategy C. Corporate strategy, corporate capture: food and alcohol industry lobbying and public health. Crit Soc Policy 2010;30:564-89.

22 Millstone E, Lang T. Risking regulatory capture at the UK's food standards agency? Lancet 2008;372:94-5.

23 Graham T, Alderson P, Stokes T. Managing conflicts of interest in the UK National Institute for health and care excellence (NICE) clinical guidelines programme: qualitative study. PLoS One 2015;10:e 0122313.

24 Brasil. Lei n. 12.813, de 16 de maio de 2013. Dispõe sobre o conflito de interesses no exercício de cargo ou emprego do Poder Executivo Federal e impedimentos posteriores ao exercício do cargo ou emprego. Diário Oficial da União 17 mai 2013;Seção 1. 